\title{
Isolation and Molecular Identification of Hydrocarbon Degrading Bacteria from Contaminated Soil in Mechanic Village Dutse, Jigawa State
}

\author{
Ringim Mahi Saidu*, Gumel Ahmad Mohammed, Shiaka Gimba Peter \\ Department of Microbiology and Biotechnology, Faculty of science, Federal University Dutse, Dutse City, Jigawa State, Nigeria \\ Email address: \\ Mahiringim007@gmail.com (R. M. Saidu),dr.gumel@fud.edu.ng(G. A. Mohammed), gimpet1971@gmail.com (S. G. Peter) \\ ${ }^{*}$ Corresponding author
}

To cite this article:

Ringim Mahi Saidu, Gumel Ahmad Mohammed, Shiaka Gimba Peter. Isolation and Molecular Identification of Hydrocarbon Degrading Bacteria from Contaminated Soil in Mechanic Village Dutse, Jigawa State. International Journal of Microbiology and Biotechnology. Vol. 5, No. 1, 2020, pp. 28-33. doi: 10.11648/j.ijmb.20200501.15

Received: January 26, 2020; Accepted: February 12, 2020; Published: February 19, 2020

\begin{abstract}
The spillage of oil and other petroleum products have been a major source of environmental pollution globally. Rampant use of chemical remediation methods were shown to be noxious with detrimental consequences. Exploration of microbiodata for probable candidate to be utilized for degradation of oil spillage or contamination is of great interest. In this study, soil samples from 10 different mechanic workshops in mechanic village Dutse were collected as well as control sample from unpolluted hydrocarbon free soil at same site, bacterial species were isolated, identified using biochemical and molecular 16S rRNA gene sequencing and post sequencing analyses. Species enumerated were Bacillus cereaus, Bacillus subtilis, Bacillus licheniformis and Paenibacillus alvei, The sequences were compared to closest relative species in the GenBank data base of National Centre for Biotechnology Information. However, the substrate used was engine oil and all the isolates were found to utilized the test substrate. Biodegradation studies have been carried out through Gas Chromatography Mass Spectrometry (GC-MS). Of all the isolates, Bacillus subtilis might be the most hydrocarbon degrading bacterial species due to high average relative abundance concentration of degraded hydrocarbon compound.
\end{abstract}

Keywords: Bacteria, Bioremediation, Hydrocarbon, Oil Spill, Petroleum, Pollution, Polymerase Chain Reaction (PCR)

\section{Introduction}

The growth of petroleum industry in Nigeria and the demand of petroleum products have made oil pollution a serious environmental problem. In mechanic workshops, there are accidental or deliberate releases or discharge of petrol, diesel, solvents, grease and lubricants on soil.

Contamination of the environment may result from seepage from natural deposits, transportation and storage of petroleum products or from accidental events [3]. Whatever the origin of the contamination, there is possibility that some may enter the soil environment and this may present a direct risk of ground water contamination, lakes or water-course that serve as stable water supply for domestic and industrial use. Although a significant proportion of the compounds in crude oil are relatively harmless, a number, especially the aromatic hydrocarbons are toxic or mutagenic and require remedial action to ameliorate environmental damage following a spill. Certain diseases namely cancer, bone marrow damage and kidney and liver diseases have been associated with the high concentration of petroleum spills compounds [17].

Along this line, natural ecosystems are contaminated with petroleum hydrocarbons, and microbial species are capable of degrading the spilled hydrocarbons [25]. Thus one of the best approaches to restoring contaminated soils is to make use of microorganisms capable of degrading those toxic compounds a process known as bioremediation [9]. Hydrocarbon degrading bacteria and fungi are mainly responsible for the mineralization of oil pollutants and are distributed in diverse ecosystems [13].

Mechanical and chemical methods for remediation of hydrocarbon-polluted environments are often expensive, technologically complex and lack public acceptance [24]. Thus bioremediation remains the method of choice for effective 
removal of hydrocarbon pollutant in the environment [16].

The speed and efficiency of bioremediation of a soil contaminated with petroleum and petroleum products depends on the number of hydrocarbon degrading microorganisms in the soil. The most important factors for population growth are temperature, oxygen, $\mathrm{pH}$, hydrocarbon class and their effective concentration. Moreover, the degree and rate of biodegradation are influenced by the type of soil in which the process occurs [10].

Automobile contaminated sites contain a variety of aliphatic, aromatic and polycyclic aromatic hydrocarbons (PAHs). Among them, polycyclic aromatic hydrocarbons pose more threat to environment and human health [11]. It has been reported that biological degradation appears to be the main process responsible for the removal of polycyclic aromatic hydrocarbons in soil [20].

Several bacteria species were known to feed exclusively on hydrocarbons as such generate their energy on hydrocarbons [26]. Acinetobacter species are found to be capable of utilizing n-alkanes of chain length $\mathrm{C}_{10}-\mathrm{C}_{40}$ as a sole source of carbon [22]. Bacterial genera namely, Gordonia, Mycobacterium, Brevibacterium, Aeromicrobium, Dietzia, Burkholderia and Pseudomonas isolated from petroleum contaminated soil proved to be the potential organisms for hydrocarbon degradation [6].

In this study, oil contaminated soil samples from mechanic sites in Dutse metropolis were used to isolate petroleum hydrocarbon degrading bacteria. The study is aimed at providing an insight to the utilization of microbial diversity in solving one of the Nigeria's eminent pollution problem.

\section{Materials and Methods}

\subsection{Study Area}

Mechanic village is located in metropolitan Dutse Local Government Area of Jigawa State, Nigeria. It is located in the eastern part of the city. The geographical location of the state is between latitudes $11.00^{\circ} \mathrm{N}$ to $13.00^{\circ} \mathrm{N}$ and longitudes $8.00^{\circ} \mathrm{E}$ to $10.15^{\circ} \mathrm{E}$ (Dutse Capital Development Authority, 2012).

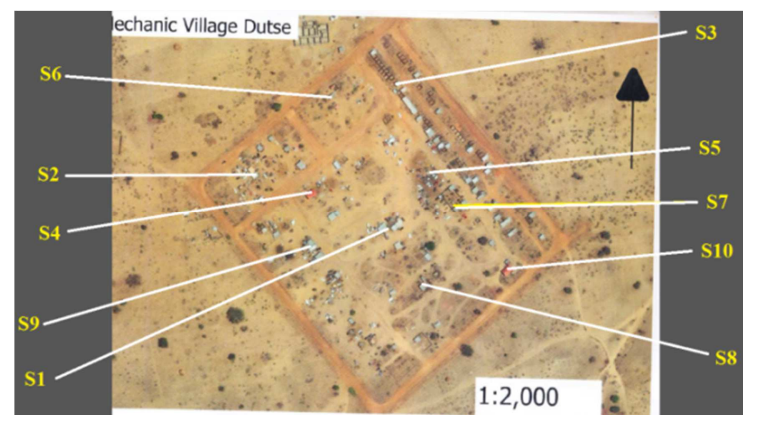

Source: Dutse Capital Development Authority (DCDA).

Figure 1. Satellite pictogram of Mechanic village. Scale: $1: 2,000 \mathrm{~cm}$ (sampling sites $\mathrm{S} 1$ to S10).

\subsection{Sample Collection}

Soil samples were collected from ten different mechanic garages situated at different locations within the Mechanic village (Figure 1). Soil sample which serve as control was also collected from unpolluted and hydrocarbon free soil at same site. Soil samples were collected by the use of sterile dark polythene bag and sterile spatula at the depth of $10 \mathrm{~cm}$ [12] and transported to Microbiology Laboratory, Federal University Dutse for further processing.

\subsection{Determination of Physicochemical Parameters of the Soil}

Physicochemical analyses were performed in the Microbiology Laboratory, Federal University Dutse. Soil pH was determined using digital $\mathrm{pH}$ meter. Temperature of the soil was measured at the point of sample collection using mercury in glass thermometer. Organic matter/organic carbon content of the soil was estimated using method deployed by Ritesh [18]. The moisture content of the soil was estimated using the procedure described by NCTEL [15].

\subsection{Isolation of Hydrocarbon Degrading Bacteria}

Hydrocarbon degrading bacteria were isolated from oil contaminated soil. Media used was Trypicase Soy Agar (TSA). Pour plate inoculation method was carried out, before pouring the medium peteridishes contained $0.05 \mathrm{~g}$ drop of petroleum supplement (engine oil), with $1 \mathrm{ml}$ from sample $10^{-}$ ${ }^{1}$ to $10^{-8}$ range of serial dilutions, which consist of mineral salts composed of $2.0 \mathrm{~g}$ of $\mathrm{Na}_{2} \mathrm{HPO}_{4} .2 \mathrm{H}_{2} \mathrm{O}, 0.8 \mathrm{~g}$ of $\mathrm{KH}_{2} \mathrm{PO}_{4}$, $0.2 \mathrm{~g}$ of $\mathrm{MgSO}_{4}$ and $1.8 \mathrm{~g}$ of $\left(\mathrm{NH}_{4}\right)_{2} \mathrm{SO}_{4}$ in $1 \mathrm{~L}$ of distilled water [21]. Four prepared dishes for each sample (making 44 dishes including control sample) were incubated at $37^{\circ} \mathrm{C}$ for $48 \mathrm{hrs}$ after which colonies were counted and expressed in colony-forming unit (cfu/g of soil) [4]. Isolates were identified on basis of colony morphology, gram staining and biochemical characteristics after incubation [8].

\subsection{Molecular Identification of Hydrocarbon Degrading Bacteria}

DNA extraction and PCR amplification of 16S rRNA were carried out at DNA LABS Nigeria Ltd, Kaduna. The total DNA of five selected isolates were extracted using DNA extraction kit. The extracted DNA was stored at $-20^{\circ} \mathrm{C}$ before subjected to PCR.

Extracted DNA was amplified using universal forward and reverse primers (Ribos 1 and Ribos 2). Each PCR mixture contained $1 \mu \mathrm{l}$ of each primer. PCR ramping amplification temperatures were as follows: Pre-Denaturation at $95^{\circ} \mathrm{C}$ for 5 minutes, Denaturation at $94^{\circ} \mathrm{C}$ for 1 minute, annealing at $52^{\circ} \mathrm{C}$ for 1 minute. Extension was observed at $72^{\circ} \mathrm{C}$ for 1 minute. Final Extension at $72^{\circ} \mathrm{C}$ for 7 minutes. The PCR amplification process was observed at 25 cycles. After the completion of the PCR, the DNA amplicons were separated by electrophoresis using $2 \%$ agarose gel [8].

\subsection{Sequencing of $16 \mathrm{~S} r \mathrm{RNA}$ and Phylogenetic Analysis}

The purified PCR product was sequenced using Dye 
terminator sequencing quick start kit. Sequences were then compared to those in Gen Bank database of the National Center for Biotechnology Information (NCBI) using website for BLAST (www.ncbi.nlm.nih.go). The sequences were aligned and the phylogenetic tree was constructed [8].

\subsection{Biodegradation Studies}

The biodegradation activities of each isolate was obtained using Gas chromatography tandem mass spectrometry (GCMS) carried out at Chemistry Laboratory, ABU Zaria. The GC-MS method deployed is as follows: $1 \mu 1$ of the methanolyzed sample mixture consisted of colonies of the test organisms and gel agar around petroleum supplement (prepared at Microbiology/Biotechnology Lab, FUD) was injected into the GC-MS at a split ratio of 1:10 and Helium gas was used as a carrier gas at a flow rate of $48 \mathrm{ml} / \mathrm{min}$ and 0.40 bar. The GC injector temperature was set at $120^{\circ} \mathrm{C}$, while the oven and column ramping temperature was set as follows: $45^{\circ} \mathrm{C}$ hold for $2 \mathrm{~min}$, rise to $120^{\circ} \mathrm{C}$ at $5^{\circ} \mathrm{C} / \mathrm{min}$ and hold for $3 \mathrm{~min}$, rise to $150^{\circ} \mathrm{C}$ at $10^{\circ} \mathrm{C} / \mathrm{min}$ hold for $2 \mathrm{~min}$, rise to $200^{\circ} \mathrm{C}$ at $20^{\circ} \mathrm{C} / \mathrm{min}$ and hold for $5 \mathrm{~min}$. This interface temperature was set at $200^{\circ} \mathrm{C}$. Mass Spectra was collected at 1250 scan rate using ion source temperature of $280^{\circ} \mathrm{C}$ and $70 \mathrm{eV}$. National Institute of Standard and Testing, USA data base was used for similarity parsing to established the identity of the degradation product [19].

\section{Results and Discussion}

\subsection{Physicochemical Parameters of the Contaminated and Control Soil Samples}

Physicochemical parameters were the most dominant factor of bacterial community distribution and abundance. Soil sampling properties are presented in Table 1.

Table 1. Mean Physicochemical characteristics of the contaminated and uncontaminated soil samples.

\begin{tabular}{|c|c|c|c|c|c|c|c|c|c|c|c|}
\hline \multirow{2}{*}{ Parameters } & \multicolumn{10}{|c|}{ Contaminate Soil Sample } & \multirow{2}{*}{$\begin{array}{l}\text { Control Soil Sample } \\
\text { CS }\end{array}$} \\
\hline & S1 & S2 & S3 & S4 & S5 & S6 & S7 & S8 & S9 & S10 & \\
\hline Temperature $\left({ }^{\circ} \mathrm{C}\right)$ & 41 & 40 & 35 & 36 & 39 & 42 & 38 & 45 & 44 & 45 & 42 \\
\hline $\mathrm{pH}$ & 7.5 & 7.6 & 7.9 & 8.1 & 8.2 & 7.2 & 7.9 & 6.9 & 7.3 & 6.1 & 5.5 \\
\hline Moisture (\%) & 3.1 & 2.8 & 3.7 & 0.8 & 3.1 & 2 & 4.8 & 3.7 & 5.1 & 2 & 8.6 \\
\hline Organic Matter (\%) & 7.3 & 7.4 & 7.5 & 8.6 & 8 & 8.6 & 7.3 & 8.9 & 8.7 & 6.7 & 1.3 \\
\hline
\end{tabular}

In this research work the temperature of the obtained contaminated soil samples are in range of $35^{\circ} \mathrm{C}$ to $45^{\circ} \mathrm{C}$, while control soil sample had $42^{\circ} \mathrm{C}$. Previous study reported similar temperature values $\left(10^{\circ} \mathrm{C}-40^{\circ} \mathrm{C}\right)$ required for effective bioremediation [12].

The $\mathrm{pH}$ values ranged from 6.9 to 8.2 for contaminated soil sample while control soil sample had 5.5. It has been reported that the $\mathrm{pH}$ value of soil contaminated with petroleum products lie within the limit of $\mathrm{pH} 6$ to 8 as most appropriate range of bioremediation [23, 24]. Our findings strongly agreed with that of Less and Senior, (1995), that $\mathrm{pH}$ value required for effective bioremediation is 5.5 to 8.5.

The moisture contents of the contamination site ranged from $0.8 \%$ to $5.1 \%$, which is lower than the value obtained from uncontaminated site $8.6 \%$. The low moisture contents observed in the contaminated site is attributed to the presence of oil in the soil, which result in the blocking of the pores; hence, the low water retention [14].

The organic matter content ranged from 6.7 to $8.9 \%$ for contaminated soil sample while $1.3 \%$ for control sample. This showed that isolates are capable of utilizing the petroleum products found in the soil environments, as their source of carbon and hydrogen. Bacteria utilized the carbon obtains from used motor oil for growth in the soil [1]. In a similar research work carried out revealed that, the organic matter content in the automobile contaminated site is higher than that of uncontaminated site, this indicated that bacteria utilized the carbon obtain from used motor oil for growth in the soil [5]. This also confirms the report that certain bacteria do utilized petroleum hydrocarbons [2].
Furthermore, additional research revealed that the total hydrocarbon content of the soil sample is greater than the intervention value cited by Dutch standard (40mg PAH/kg soil and $0.1 \mathrm{mg}$ volatile hydrocarbon $/ \mathrm{kg}$ soil) [8]. So, the soil sample are highly polluted by hydrocarbon. Comparative study of oil biodegradation is also defending on the type of soil which shows that, the microorganism activity is related to the soil water content [19].

\subsection{Bacterial Enumeration of Contaminated and Control Soil Samples}

The bacterial culture was observed and counted as shown in Table 2 below.

Table 2. Mean Bacterial count and cultural characteristics from contaminated and uncontaminated sites.

\begin{tabular}{lll}
\hline $\begin{array}{l}\text { Contaminated } \\
\text { Soil Samples }\end{array}$ & $\begin{array}{l}\text { Cultural } \\
\text { Characteristics }\end{array}$ & $\begin{array}{l}\text { Bacterial load } \\
(\mathbf{c f u} / \mathbf{m l})\end{array}$ \\
\hline S1 & Creamy Yellow & $230 \times 10^{-5}$ \\
S2 & Creamy White & $196 \times 10^{-3}$ \\
S3 & Creamy White & $148 \times 10^{-3}$ \\
S4 & Creamy Yellow & $292 \times 10^{-4}$ \\
S5 & Creamy Yellow & $128 \times 10^{-4}$ \\
S6 & Creamy Yellow & $108 \times 10^{-3}$ \\
S7 & Yellow & $188 \times 10^{-2}$ \\
S8 & Creamy White & $220 \times 10^{-2}$ \\
S9 & Creamy Yellow & $76 \times 10^{-5}$ \\
S10 & Creamy Yellow & $22 \times 10^{-6}$ \\
CS & Yellow & TNTC \\
\hline
\end{tabular}

CS: control sample; TNTC: Too numerous to count. 
The bacterial colony counts of soil samples from both contaminated and uncontaminated sites as presented in Table 2 showed that the uncontaminated site had the highest counts. This indicates that the petroleum products in the contaminated sites had adversely affect the growth of the organisms [7]. In a similar study carried out shows that, automobile uncontaminated site had the highest bacterial count when compared with bacterial count of automobile contaminated site. This indicated that the petroleum products in the contaminated sites have adversely affect the growth of the organisms [5].

\subsection{Morphological and Biochemical Characteristics of Bacterial Isolates}

These microscopic and biochemical characteristics of bacterial isolates in contaminated soil samples are presented in Table 3.

Table 3. Cultural and biochemical characteristics of bacterial isolates from contaminated soil.

\begin{tabular}{|c|c|c|c|c|c|c|c|c|c|c|c|c|}
\hline Samples & GR & Shape & MP- TSA & Cat & Coa & Ur & Cit & Ind & MR & VP & Oxi & Lip \\
\hline S1 & + & Cocci in Clusters & Creamy Yellow & + & + & - & + & - & - & + & - & + \\
\hline S2 & + & Bacilli short chain \& singles & Creamy White & + & - & - & + & - & - & + & - & + \\
\hline $\mathrm{S} 3$ & + & Bacilli short chain \& singles & Creamy White & + & - & - & + & - & - & + & - & + \\
\hline S4 & + & Bacilli long chain & Creamy Yellow & + & - & - & + & - & - & + & - & + \\
\hline S5 & + & Cocci in Clusters & Creamy Yellow & + & + & - & + & - & - & + & - & + \\
\hline S6 & + & Bacilli short chain \& pairs & Creamy Yellow & + & - & - & + & + & - & + & + & + \\
\hline S7 & + & Cocci long chain & Yellow & + & - & - & + & - & - & + & - & + \\
\hline S8 & + & Bacilli single & Creamy White & + & - & - & + & - & - & + & - & + \\
\hline S9 & + & Cocci Clusters & Creamy Yellow & + & - & - & + & - & - & + & - & + \\
\hline $\mathrm{S} 10$ & + & Cocci Clusters & Creamy Yellow & + & - & - & + & - & - & + & - & + \\
\hline
\end{tabular}

GR: Gram staining; MP-TSA: Morphology on TSA; Cat: Catalase; Coa: Coagulase; Ur: Urase; Cit: Citrate; Ind: Indole; MR: Methayl red; VP: Voges proskeur; Oxi: Oxidase; Lip: Lipase.

The colonies were rod shape and circular. Additional biochemical tests were carried out to identify the isolates strain as shown in table 3 above.

\subsection{Biodegradation Studies of the Isolates from Contaminated Soil Sample}

Table 4 showed various biodegrading compounds and relative abundance of the isolates through GC-MS.

Table 4. Biodegradation abilities of bacterial isolates from contaminated soil samples through GC-MS.

\begin{tabular}{lllll}
\hline Samples & Compound Name & Compound Formular & Retention Time & Average relative abundance (conc. $\mu$ g/ $\boldsymbol{\mu l}$ ) \\
\hline S2 & Allyl methallyl ether & $\mathrm{C}_{7} \mathrm{H}_{12} \mathrm{O}$ & $15: 48 \mathrm{sec}$ & 2395.77 \\
S3 & Ethanamine, N-ethyl- & $\mathrm{C}_{4} \mathrm{H}_{11} \mathrm{~N}$ & $14: 57 \mathrm{sec}$ & 549.85 \\
S4 & Oxalic acid, allylpendadecyl ester & $\mathrm{C}_{20} \mathrm{H}_{36} \mathrm{O}_{4}$ & $27: 49 \mathrm{sec}$ & 194.28 \\
S5 & Formaldehyde, dimethylhydrazone & $\mathrm{C}_{3} \mathrm{H}_{8} \mathrm{~N}_{2}$ & $14: 30 \mathrm{sec}$ & 24.98 \\
\hline
\end{tabular}

Biodegradation capabilities through GC-MS of the isolates presented in Table 4 above, showed different kinds of hydrocarbon compounds specifically utilized by the isolates in the process of obtaining their nutrient using hydrocarbon as a source of energy. It is showed that Bacillus subtilis might have more degradation capabilities over the identified organisms with average relative abundance of $2395.77 \mu \mathrm{g} / \mu \mathrm{l}$.

\subsection{Molecular Identification of Test Organisms from Contaminated Soil Sample}

Table 5 presented the test organisms identified at molecular level from corresponding five samples through DNA extraction, PCR and gene sequencing.
Table 5. Identified organisms from contaminated soil samples using molecular techniques.

\begin{tabular}{ll}
\hline Samples & Identified Organisms \\
\hline S1 & Bacillus cereus \\
S2 & Bacillus subtilis \\
S3 & Bacillus licheniformis \\
S4 & Paenibacillus alvei \\
S5 & Bacillus licheniformis \\
\hline
\end{tabular}

Genomic DNA was isolated from all isolates, a PCR products of $789 \mathrm{bp}$ of the five isolates were analysed on agarose gel electrophoresis (Figure 2). Based on the 16S rRNA gene sequencing and phylogenetic analysis (Figure 3), the isolates (Bacillus cereus, Bacillus subtilis, Bacillus licheniformis and Paenibacillus alvei) were identified compared to the closet relative species in the GenBank data base. 


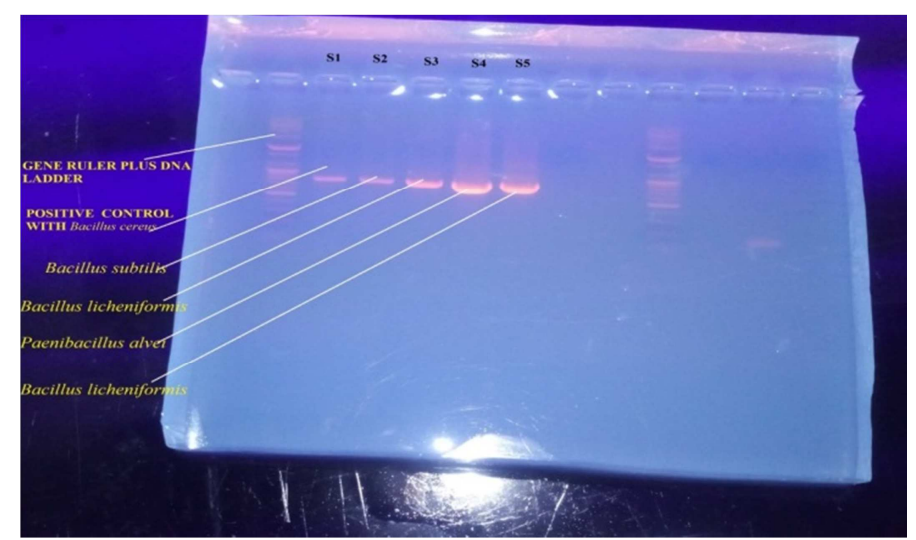

Figure 2. Agarose gel electrophoresis of PCR amplification product of bacterial isolates using primers: Gene ruler plus DNA ladder, the lane showed positive control with all the 5 isolates with $789 \mathrm{bp}$.
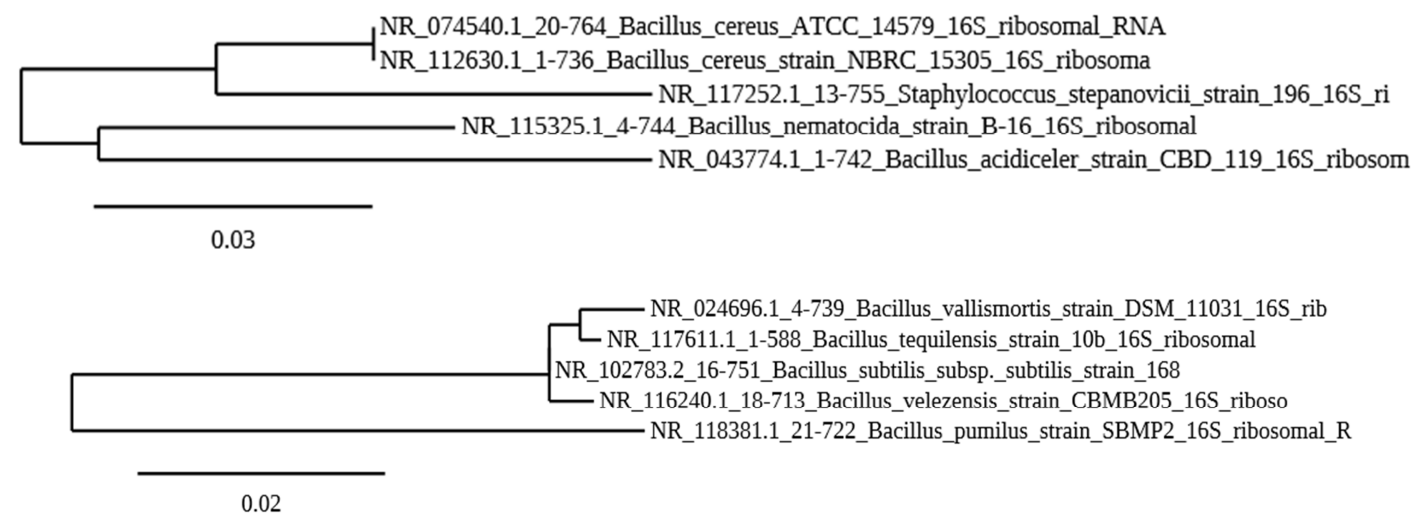

NR_148273.1_54-304_Bacillus_haikouensis_strain_C-89_16S_ribosoma NR_148273.1_1-209_Bacillus_haikouensis_strain_C-89_16S_ribosomal

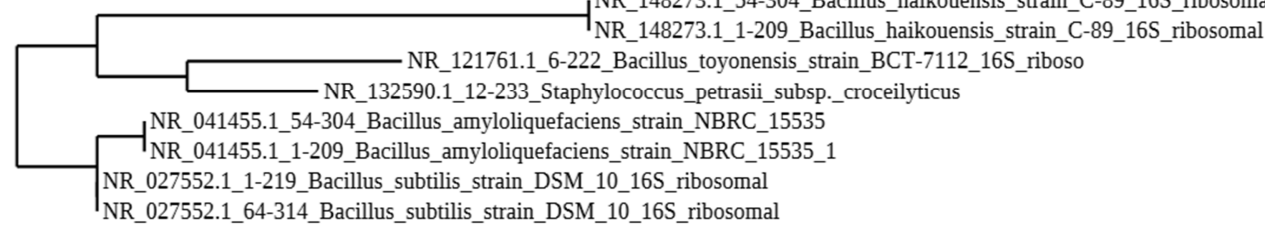

0.08

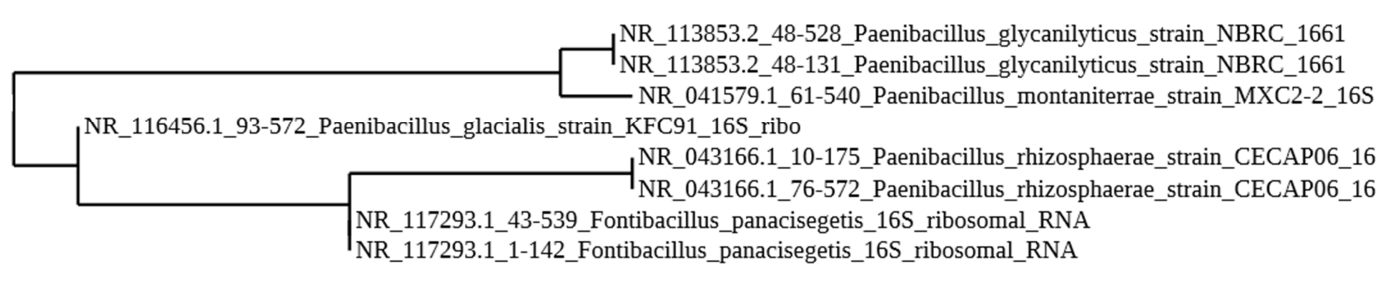

0.09

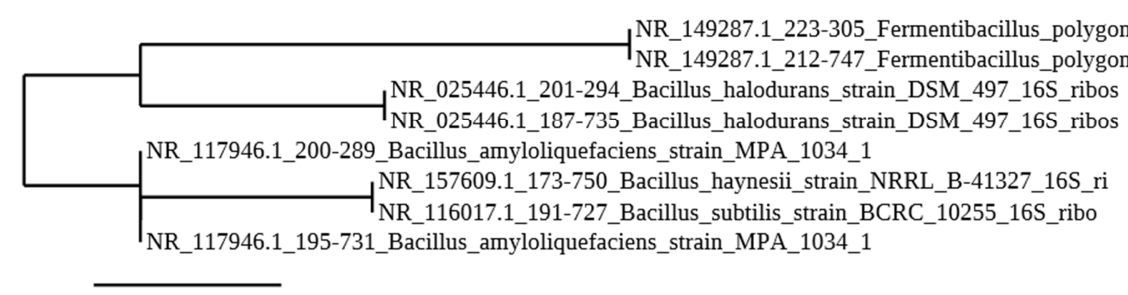

0.01

Figure 3. Phylogenetic tree based on the partial 16S rRNA gene sequences of the five isolates (Bacillus cereus, Bacillus subtilis, Bacillus licheniformis, Paenibacillus alvei and Bacillus licheniformis respectively) and related species found by a BLASTn database search. 


\section{Conclusion}

Bacteria capable of utilizing and degrading used petroleum products (petrol and engine oil) exist in contaminated soil with these products at Mechanic village Dutse. In this current study, five bacterial strains were isolated from ten different oil contaminated garages in mechanic site. These strains have significant ability to utilize petrol and waste engine oil as a sole source of carbon and energy. On the basis of morphological, biochemical and molecular identification, Bacillus cereus, Bacillus subtilis, Bacillus licheniformis, Paenibacillus alvei and Bacillus licheniformis were identified. This study reported that Bacillus subtilis might had the highest hydrocarbon degradation ability. The ability of these strains to degrade hydrocarbon in oil polluted site suggested that they could be used for the treatment of other oil wastes in soil and ground water. Additional works will be suggested in our future research for the application of bioremediation using isolated strains.

\section{References}

[1] Abdulsalam, S., Adefila, S. S., Bugaje, I. M. and Ibrahim, S. C (2012). Bioremediation of soil contaminated with used motor oil in a closed system. J. Bioremediation and Biodegradation 3 (12): 1-7.

[2] Alexander M. (2004). Biodegradation and Bioremediation. San Diego: Academic press, PP 43-48.

[3] Balba M. T., Al-Awadhi N, Al-Daher R. (2008). Bioremedition of oil- contaminated soil; Microbiological Methods for feasibility assessment and field evaluation. $J$. Microbiol. Methods, 32: 155-164.

[4] Benson, H. J. (1994). Microbiological Applications seventh edition; Laboratory Manual in General Microbiology. McGraw-Hill 22: 26-31.

[5] Binta L. M (2014). Studies on the Hydrocarbon-utilization Potentials of Bacteria and Fungi Isolated from Soil Contaminated with Petroleum Products in Kano, Nigeria. Pp 22-43.

[6] Chailan, F., Le Fleche, A., Bury, E., Phantavog, Y. H., Grimont, P., Saliot, A. and Oudot, J. (2004). Identification and biodegradation potential of tropical aerobic hydrocarbon degrading microorganisms. Research in microbiology.

[7] Eja, M. E., Udo S. M and Asikong, B. E (2005). Bioremediation Potential of Bacillus species in oil polluted soil from automechanic workshops in Calabar, Nigeria, Africa J. Environ. Pullut. Health 2 (1): 11-18.

[8] Fatiha D., Abdelwahed C., Khadidja S. R. (2017). Isolation and Molecular Identification of hydrocarbon degrading bacteria from oil contaminated soil. Internl. Journal of Bioscience. ISSN: 2220-6655. Vol. 11, No. 4, p. 272-278.

[9] Fatima M., Flavio A., Benedict C., Williams T. (2005). Comparative bioremediation of soils contaminated with diesel oil by natural attenuation, biostimulation and bioaugmentation. Bioresource Tech., 96: 1049-1055.
[10] Hamme, J. D., Van A., Singh, O. P. (2003) Microbiol. Mol Biol. Rev. 67: 503.

[11] Howsam, M. and Jones, K. C (2008), "sources of PAHs in the environment. In: Neilson AH (ed). Anthropogenic compounds. PAHs and related compounds" springer, Berlin, Germany, pp 137-174.

[12] Ismaila, S. (2008): Bioremediation laboratory manual. Department of Biotechnology, Islamic University, Gaza, Israel pp 971-999.

[13] Leahy J. G, Colwell R. R (2000). Microbial degradation of hydrocarbons in the environment. Microbial. Rev, 54: 305315 .

[14] Less Z. M., Senior, E. (1995). Bioremediation. A practical solution to land pollution. In: Clean Technology and the Environment chapman and Hall, New York. 121-146 (26 years).

[15] NITTTR, Chandigarh Technology Enabled Learning (NCTEL). Dec., 2013. Determination of water content of soil by oven drying method- youtube.

[16] Okoh, A. I and M. R. Trejo-Hermandez, (2006). Remediation of petroleum hydrocarbon polluted systems: exploiting the bioremediation strategies. African J. Biotechnol, 5: 25202525 .

[17] Olakunle, F. (2013). Characterization of indigenious microorganisms associated with crude oil polluted soil and water. Microbiology journal 56: 2567-2569.

[18] Ritesh K. N. (2012). Determination of organic carbon of soil. Made with KINEMASTER-youtube.

[19] Scherrer P., Mille G. (1990). Biodegradation of crude oil in experimentally-polluted clayey and sandy mangrove soils. Oil and Chemical Pollution 6, 163-176.

[20] Sims, R. C and Overcash, M. R (2014), "Fate of polynuclear aromatic compounds (PNAs) in soil-plant system" Res Rev., 88, pp 1-67.

[21] Soriano M. and Pereira, D. C. (1998). Nutrient removal from aquaculture wastewater using macroalgae Garcilaria birdiae. Biomass and Bioenergy 33: 327-331.

[22] Throne-Host, M., Wentzel, A., Ellingsten, T. E., Kotlar, H. K. and zotcher, S. B. (2007). Identification of novel genes involved in long-chain n-alkane degradation by Acinetobacteria sp. Applied and environmental microbiology.

[23] United States Environment Protection Agency (USEPA) (2015): Characteristics of spilled oils, fuels and Petroleum products; composition and properties. May, 2015.

[24] Vidali M (2010), “Bioremediation; An overview;” pure Appl. Chem., 73 (7), pp 1163-1172.

[25] Widdle F. and Rabus R. (2001). Anaerobic Biodegradation of Saturated and Aromatic hydrocarbons. Curr. Opin. Biotechnol., 12: 259-276.

[26] Yakimov, M. M., Timmis, K. N and Golyshin, P. N. (2007). Obligate oil degrading marine bacteria. Current opinions in Biotechnology. 